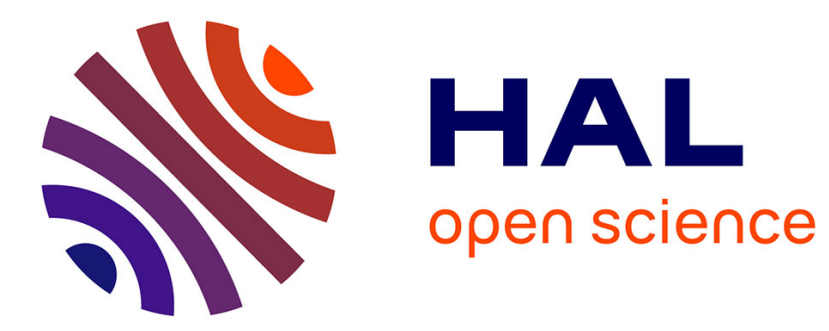

\title{
Insulin immuno-neutralization in fed chickens: effects on liver and mucle transcriptome
}

Jean Simon, Dragan Milenkovic, Estelle Godet, Cédric Cabau, Anne Collin, Sonia Metayer-Coustard, Nicole Rideau, Sophie Tesseraud, Michel Derouet, Sabine Crochet, et al.

\section{To cite this version:}

Jean Simon, Dragan Milenkovic, Estelle Godet, Cédric Cabau, Anne Collin, et al.. Insulin immunoneutralization in fed chickens: effects on liver and mucle transcriptome. Physiological Genomics, 2012, 44 (5), pp.283-292. 10.1152/physiolgenomics.00057.2011 . hal-01129580

\section{HAL Id: hal-01129580 \\ https://hal.science/hal-01129580}

Submitted on 29 May 2020

HAL is a multi-disciplinary open access archive for the deposit and dissemination of scientific research documents, whether they are published or not. The documents may come from teaching and research institutions in France or abroad, or from public or private research centers.
L'archive ouverte pluridisciplinaire HAL, est destinée au dépôt et à la diffusion de documents scientifiques de niveau recherche, publiés ou non, émanant des établissements d'enseignement et de recherche français ou étrangers, des laboratoires publics ou privés.

\section{다(1) (2)}

Distributed under a Creative Commons Attribution - ShareAlikel 4.0 International 


\title{
Insulin immuno-neutralization in fed chickens: effects on liver
}

\section{and muscle transcriptome}

\author{
Jean Simon, ${ }^{1}$ Dragan Milenkovic, ${ }^{2}$ Estelle Godet, ${ }^{1}$ Cedric Cabau, ${ }^{3}$ Anne Collin, ${ }^{1}$ Sonia Métayer-Coustard, ${ }^{1}$ \\ Nicole Rideau, ${ }^{1}$ Sophie Tesseraud, ${ }^{1}$ Michel Derouet, ${ }^{1}$ Sabine Crochet, ${ }^{1}$ Estelle Cailleau-Audouin, ${ }^{1}$ \\ Christelle Hennequet-Antier, ${ }^{1}$ Christian Gespach, ${ }^{4}{ }^{\text {Tom E. Porter, }}{ }^{5}$ Michel J. Duclos, ${ }^{1}$ Joëlle Dupont, ${ }^{6}$ \\ and Larry A. Cogburn ${ }^{7}$ \\ ${ }^{1}$ Station de Recherches Avicoles, ${ }^{3}$ Système d'Information des Animaux d'Elevage, and ${ }^{6}$ Physiologie de la Reproduction et des \\ Comportements, Institut National de la Recherche Agronomique (INRA), Nouzilly; ${ }^{2}$ Unité de Nutrition Humaine, INRA, Theix; \\ ${ }^{4}$ Institut National de la Santé et de la Recherche Médicale, U673 and Université Pierre et Marie Curie Paris 6, Hôpital Saint \\ Antoine, Paris, France; ${ }^{5}$ Department of Animal and Avian Sciences, University of Maryland, College Park, Maryland; \\ and ${ }^{7}$ Department of Animal and Food Sciences, University of Delaware, Newark, Delaware
}

Submitted 7 April 2011; accepted in final form 27 December 2011

Simon J, Milenkovic D, Godet E, Cabau C, Collin A, MétayerCoustard S, Rideau N, Tesseraud S, Derouet M, Crochet S, Cailleau-Audouin E, Hennequet-Antier C, Gespach C, Porter TE, Duclos MJ, Dupont J, Cogburn LA. Insulin immuno-neutralization in fed chickens: effects on liver and muscle transcriptome. Physiol Genomics 44: 283-292, 2012. First published January 3, 2012; doi:10.1152/physiolgenomics.00057.2011.—Chickens mimic an insulin-resistance state by exhibiting several peculiarities with regard to plasma glucose level and its control by insulin. To gain insight into the role of insulin in the control of chicken transcriptome, liver and leg muscle transcriptomes were compared in fed controls and "diabetic" chickens, at $5 \mathrm{~h}$ after insulin immuno-neutralization, using $20.7 \mathrm{~K}$ chicken oligo-microarrays. At a level of false discovery rate $<0.01$, 1,573 and 1,225 signals were significantly modified by insulin privation in liver and muscle, respectively. Microarray data agreed reasonably well with qRT-PCR and some protein level measurements. Differentially expressed mRNAs with human ID were classified using Biorag analysis and Ingenuity Pathway Analysis. Multiple metabolic pathways, structural proteins, transporters and proteins of intracellular trafficking, major signaling pathways, and elements of the transcriptional control machinery were largely represented in both tissues. At least 42 mRNAs have already been associated with diabetes, insulin resistance, obesity, energy expenditure, or identified as sensors of metabolism in mice or humans. The contribution of the pathways presently identified to chicken physiology (particularly those not yet related to insulin) needs to be evaluated in future studies. Other challenges include the characterization of "unknown" mRNAs and the identification of the steps or networks, which disturbed tissue transcriptome so extensively, quickly after the turning off of the insulin signal. In conclusion, pleiotropic effects of insulin in chickens are further evidenced; major pathways controlled by insulin in mammals have been conserved despite the presence of unique features of insulin signaling in chicken muscle.

diabetes; gene expression; insulin-responsive genes; signaling pathways and metabolism

IN ADDITION TO PROVIDING A valuable source of human food, chickens exhibit several physiological peculiarities, particularly glucose metabolism and its endocrine control. For example, chickens exhibit constitutively high glycemia $(1.8-2.0 \mathrm{~g} / \mathrm{l}$, in the fasted status) despite the presence of an endogenous

Address for reprint requests and other correspondence: J. Simon, Station de Recherches Avicoles, INRA, 37380 Nouzilly, France (e-mail: simon@tours. inra.fr). hyperactive insulin circulating at rather "normal" levels (39). Additional hallmarks of avian metabolism are the requirement for a high dose of exogenous insulin to induce hypoglycemia and the survival of chickens following administration of a large dose of exogenous insulin, which would be lethal in mammals. Although normal for the chicken, these characteristics mimic Type 2 diabetes in mammals $(11,12)$. Furthermore, the mechanism of insulin signaling remains enigmatic or even provocative in chicken muscle. The early steps of insulin signaling [i.e., tyrosine phosphorylation of insulin receptor beta-subunit and substrate- 1 and phosphatidylinositol-3 kinase (PI3K) activity] appear insensitive to insulin status, whereas steps downstream of PI3K are accordingly sensitive to insulin $(11,12)$.

Insulin immuno-neutralization in young fed chickens (i.e., a nutritional status with high demand in insulin) rapidly induces large increases in plasma levels of glucose (up to 4.3 or $7.5 \mathrm{~g} / \mathrm{l}$ at 1 or $5 \mathrm{~h}$, respectively), nonesterified fatty acids, and amino acids. Acute insulin deprivation alters several steps in the insulin signaling cascade and other components of the endocrine system: plasma glucagon, triiodothyronine (T3), and insulin-like growth factor binding protein-1 (IGFBP1) levels (11). Furthermore, several mRNAs coding for specific transcription factors or metabolic enzymes, selected a priori as potentially insulin sensitive, were altered at $5 \mathrm{~h}$ of insulin privation in liver and skeletal muscle (leg muscle). Some of these changes were insulin specific, since fasting for $5 \mathrm{~h}$ did not induce the same alterations in gene expression as did insulin deprivation. Therefore, insulin appears to also exert pleiotropic effects in fed chickens, which had been previously doubtful (12). Interestingly, the adenosine monophosphate kinase (AMPK) system was not activated in liver or muscle following insulin privation or fasting for $5 \mathrm{~h}$. In other studies, the recruitment of the AMPK system in response to fasting requires a prolonged fasting time in the chicken (34). Together, these findings suggest that our experimental model of "diabetes" in the chicken is quite suitable for identification of the very early changes in liver and muscle transcriptome before development of long-term complications from insulin privation. Until now, microarray analysis of Type 2 diabetes or obesity have been studied mainly in rodent models or humans (42). In the present study, microarray analysis were performed in chicken liver and leg muscle samples from the insulin immunoneutralization experiment, which we described earlier (11), to 
gain a greater insight into the role of insulin in control of gene transcription in these two metabolic tissues and to evaluate whether the insulin-dependent pathways established in mammals have been conserved in the chicken. A dual benefit of this new knowledge on insulin control of metabolism in the chicken could be realized with genetic selection of leaner chickens as a healthier human food by favoring protein accretion, at the expense of lipogenesis and excessive body fatness.

\section{MATERIALS AND METHODS}

Chicken tissues and experimental conditions. Liver and leg muscle tissues were issued from our earlier study (11), where experimental conditions are described in detail. All procedures were approved by the French Agricultural Agency and the Scientific Research Agency and conducted in accordance with the guidelines for Care and Use of Agricultural Animals in Agricultural Research and Teaching. Herein, changes in liver and leg muscle transcriptome were assessed in fed chickens at $5 \mathrm{~h}$ following insulin immuno-neutralization by comparing "diabetics," insulin-deprived birds $(n=6)$, against the control group ( $n=6$ birds), which received injections of normal guinea pig serum. Total tissue RNA was extracted using RNeasy kits (Qiagen) according to manufacturer's protocol. RNA samples were further purified using a final ethanol precipitation and washing step. RNA quality was determined using Agilent apparatus (2100 Bioanalyzer). RNA samples exhibited RNA integrity number $>8$.

Fluorescent cDNA labeling. Two samples of $5 \mu \mathrm{g}$ RNA/chicken/ tissue were reverse-transcribed with $1 \mu \mathrm{l}$ of random primers and $1 \mu \mathrm{l}$ of oligo(dT) using the ChipShot Direct Labeling System kit (Promega), and fluorescent cDNA labeling was performed with either Cy3- or Cy5-dCTP (GE Healthcare). Labeled cDNAs were purified by application to an equilibrated filter cartridge using the ChipShot Membrane Clean-up System (Promega) as recommended by the manufacturer. Quantities and labeling efficiencies of labeled cDNAs were determined by measuring absorbencies at 260, 550, and $650 \mathrm{~nm}$ using a ND-1000 spectrophotometer (Nanodrop).

Hybridizations of microarrays. Hybridizations were carried out using the ChickenOligo 20.7K 70-mer microarray v1.0 oligo set, which was designed by the Roslin Institute/ARK Genomics and synthesized by Operon (http://www.operon.com/download/index.php) and spotted on Corning glass slides (lot 213) by the Centre de Ressources Biologiques, Génomique des Animaux Domestiques (http:// crb-gadie.inra.fr/). Experimental conditions ("diabetics" vs. controls) were compared using six pairs of chickens $(n=6$ chickens per experimental group) and a dye-swap hybridization design (i.e., cDNAs of each chicken pair were labeled and hybridized twice, inverting dye labeling). In all, 12 microarray slides were used for each tissue and simultaneously hybridized with a Ventana Hybridization System at $42^{\circ} \mathrm{C}$ for $8 \mathrm{~h}$. Slides were subsequently washed twice in $2 \times$ saline sodium citrate (SSC) and $0.1 \times$ SSC at room temperature. The buffer remaining on the slide was removed by rapid centrifugation $(4,000 \mathrm{~g}$ for $15 \mathrm{~s})$. The fluorescence intensity was scanned using the Agilent Micro Array Scanner G2505B.

Image and data analysis. Images were analyzed as previously described (3). The signal and background intensity values for each spot in both channels were obtained using ImaGene 6.0 software. Data were filtered using the ImaGene "empty spot" option, which automatically flags low-expressed and missing spots to be removed from the analyses. The MIAME compliant raw microarray data have been deposited in the ArrayExpress database at the European Bioinformatics Institute (http://www.ebi.ac.uk/arrayexpress/) under the accession number E-MEXP-3182. After base-2 logarithm transformation, data were corrected for systemic dye bias by Lowess normalization using GeneSight 4.1 software. Spot intensity ratios were then filtered in accordance with their variability among the six comparisons and genes (oligo spots) with high variability were removed from the analysis. Statistical analyses were performed using open source R 2.1 software (http://www.r-project.org). The $\log 2$ ratio between "diabetic" and control samples was analyzed with Student's $t$-test and used to detect differentially expressed genes in the two experimental conditions. The probability values were adjusted using the BenjaminiHochberg correction for multiple testing to control the rate of false positives [false discovery rate (FDR) $<0.01$ ]. Genes selected by these criteria are referred to as differentially expressed (DE) genes. At this level of FDR, no further arbitrary high cut-off for fold changes (FC) was applied. As shown in RESULTS, the abundance EGRI mRNA decreased in muscle following insulin deprivation as indicated by both qRT-PCR $(P<0.03)$ and microarray $(\mathrm{FC}=0.87)$ analyses, whereas liver IGFBPI messenger increased $(\mathrm{FC}=1.33$ in microarray and $P<$ 0.0001 in qRT-PCR) which accounts for the elevated levels of IGF-BP1 protein in plasma.

$q R T-P C R$ analysis. Supplemental qRT-PCR measurements were performed for two additional genes ( $a v U C P$ and $S L C 2 A 8$ ) in muscle tissue to complement of the 24 genes previously verified in our original study (11). Primer sequences were: CTATGGGATGAGAGGGACCAAAG, forward $\left(5^{\prime}-3^{\prime}\right)$ and GGAGAACCTCAACACGTTCCTTC, reverse $\left(5^{\prime}-3^{\prime}\right)$ for $a v U C P$ and CTGGAGGAATACTGGGAGGC, forward $\left(5^{\prime}-3^{\prime}\right)$ and CACCACCATCAACTGGACAA, reverse $\left(5^{\prime}-3^{\prime}\right)$ for $S L C 2 A 8$. Conditions for retro-transcription, PCR reactions, and internal references were identical to those previously used for the validation of our insulin immuno-neutralization model (11).

Assignment of DE genes to canonical pathways and visualization of gene interaction networks. To determine the major functional pathways altered by insulin privation, oligo probes having a corresponding human protein ID were classified using the Gene Ontology (GO) feature in Pathway Miner (http://www.biorag.org/index.php). Ingenuity Pathway Analysis (IPA) software (Ingenuity Systems, http:// www.ingenuity.com/) was used to visualize the major gene interaction networks populated by DE genes in liver and muscle. The human protein identification (ID) corresponding to chicken orthologs and the chicken oligo (RIGG ID number) and $\log 2$ FC (diabetics/controls) listed in Supplemental Table S1 (liver) and Supplemental Table S2 (muscle) were used as input data files for IPA. ${ }^{1}$ Although dozens of gene interaction networks were identified from microarray analysis of liver and muscle in insulin-deprived chickens, only a few representative gene interaction pathways are presented below.

\section{RESULTS AND DISCUSSION}

From the $20.7 \mathrm{~K}$ oligonucleotide probes spotted on the array, intensity signals from 3,415 and 3,287 spots entered statistical analyses for liver and muscle, respectively. Insulin privation altered the abundance of 1,573 mRNAs in liver and 1,225 in leg muscle of fed chickens, using an FDR $<0.01$ as the threshold for significance. The lists of DE genes and the log ratio changes (FC, as diabetics/controls) are provided in Supplemental Materials (Supplemental Table S1 for liver and Supplemental Table S2 for muscle). The lists contain several ID numbers: the oligo IDs [Roslin Institute Gallus gallus (RIGG number)] and when available, the Ensembl G. gallus (ENSGALG) gene ID number and the corresponding human gene and protein IDs. These IDs were obtained from Ensembl (http://www.ensembl.org/index.html) with database versions available in September 2008: 50.2h for chicken and 50.361 for human genome. A total of 276 genes (oligo spots) in liver and 207 genes in muscle had no Ensembl gene ID or corresponding human protein ID. Elucidation of the information provided by these unknown or "orphan" RIGG oligos mRNAs awaits progress in resequencing and reassembly of the chicken genome.

\footnotetext{
${ }^{1}$ The online version of this article contains supplemental material.
} 
Table 1. Number of differentially expressed $(F D R<0.01)$ genes found in liver and muscle after insulin immuno-neutralization

\begin{tabular}{lccccc}
\hline \hline \multirow{2}{*}{\multicolumn{1}{c}{ mRNAs }} & \multicolumn{2}{c}{ Liver } & & \multicolumn{2}{c}{ Muscle } \\
\cline { 2 - 3 } \cline { 5 - 6 } & $n$ & FC Range & & $n$ & FC Range \\
\hline Downregulated & 850 & $0.91-0.48$ & & 619 & $0.91-0.53$ \\
Upregulated & 723 & $2.42-1.10$ & & 606 & $1.65-1.11$ \\
\hline
\end{tabular}

Fold-change (FC) was determined as the ratio of "diabetics"/controls. FDR, false discovery rate.

Transcripts showing significant changes in their expression level were split about equally into down- or upregulated groups for both liver and muscle (Table 1). The FC ranges were also about of the same magnitude among expression groups and tissues.

Comparison between microarray data and qRT-PCR or protein level measurements. Liver FASN $(\mathrm{FC}=0.46)$ and IGFBPI $(\mathrm{FC}=1.33)$ mRNAs were respectively down- and upregulated following insulin privation, confirming previous qRT-PCR analysis (11). And as we reported earlier (11), plasma IGFBP1 protein significantly increased. The decrease in abundance of DIO2 transcript, which accounts for the decrease in plasma $\mathrm{T}_{3}$ was significant in the qRT-PCR, although the microarray data did not reach the level of significance $(\mathrm{FC}=0.94$, FDR $<0.08$ ). Other liver mRNAs, significantly different by qRTPCR analysis, either did not enter statistical analysis (EGRl, $P P A R G$, THRSPA) of microarray data or were not represented by an oligo probe on the microarray (DIO3 and SREBP 1 ).

Previous qRT-PCR analysis of 24 genes showed fewer significant changes in muscle than in liver. Muscle microarray data confirmed lower EGRI messenger $(\mathrm{FC}=0.87)$. The increase in $M U R F 1$ messenger (E3 ubiquitin-protein ligase or TRIM63), which did not reach the level of significance in qRT-PCR analysis, was significant in microarray analysis. Atrogin-1 (FBXO32, F-box only protein32) messenger, also involved in protein degradation, significantly increased in qRT-PCR but did not enter microarray analysis. A discrepancy between qRT-PCR and microarray results was observed for avian $U C P$ gene messenger ( $a v U C P$, related to human $U C P 3$ ): an increase, although at the limit of significance, in qRT-PCR vs. a large decrease in microarray analysis $(\mathrm{FC}=0.72)$. One hypothesis accounting for this discrepancy could be that several UCP3 transcripts exist in the chicken as in the case of humans. The oligo sequence printed on the microarray slide corresponds to the last exon of the avUCP gene. New qRTPCR using primers designed within this exon confirmed previous qRT-PCR results (i.e., a slight increase, data not shown). As a whole and apart from this unexplained discrepancy, our previous qRT-PCR analysis (or protein measurements) and the present microarray analysis are in good agreement for both tissues (liver and leg muscle). Furthermore, some mRNAs having an identified human counterpart were represented by two chicken oligo probes. For five of them, results of the two oligos agreed. For seven of them there was disagreement; some of these discrepancies may come from the existence of several transcripts.

Ingenuity Pathway and Pathway Miner analyses. To visualize the major canonical pathways altered by insulin privation, DE oligos having a corresponding human protein ID were first classified using Pathway Miner at Biorag (http://www.biorag.

Table 2. Ingenuity Pathway Analysis of biological processes altered by insulin deprivation in liver and muscle

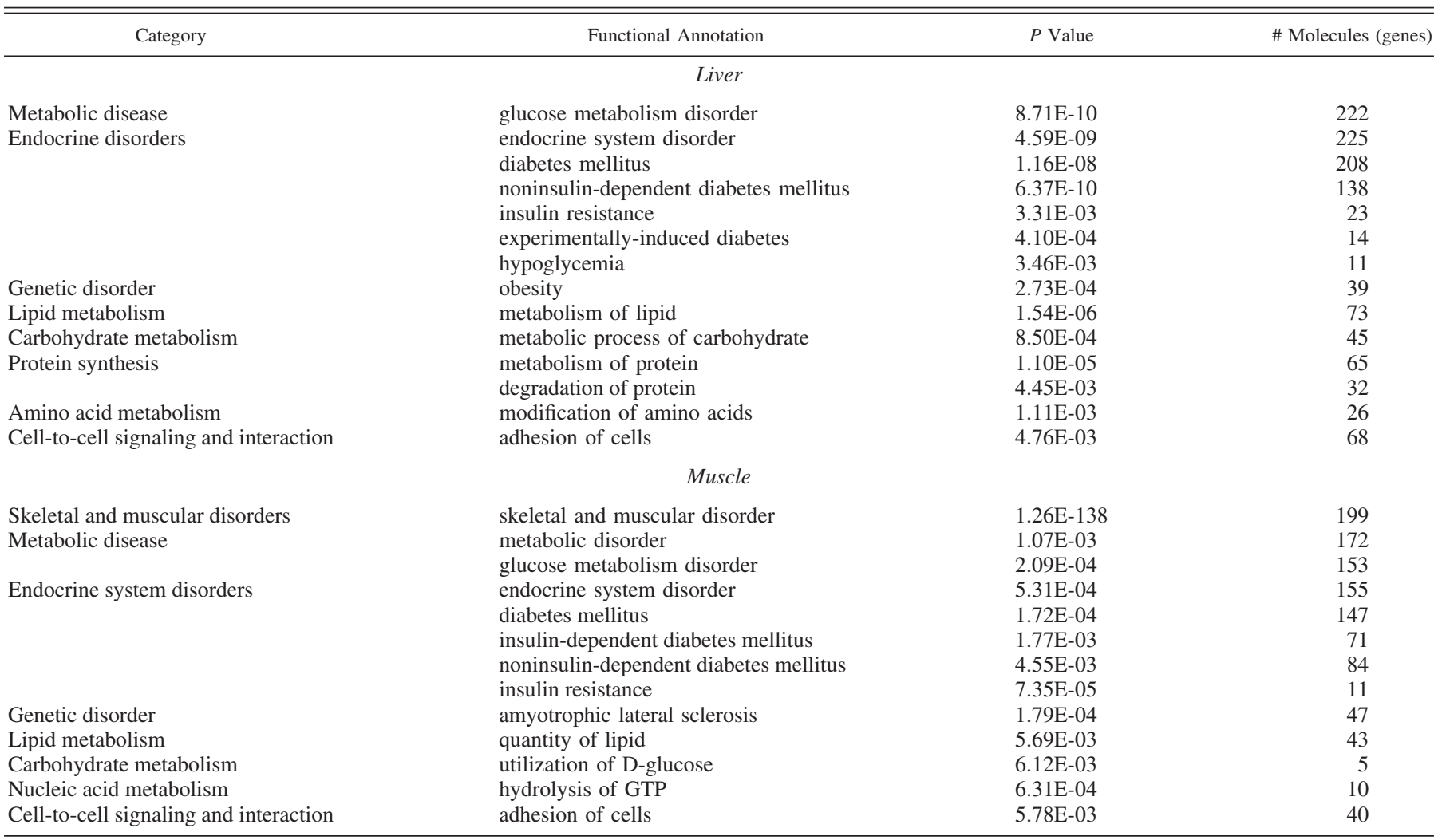


org/index.php). The lists of these genes are given in Supplemental Table S3 for liver and Supplemental Table S4 for muscle. No assumption about cut-off limit was applied since relatively small changes could have important physiological consequences. For instance, as discussed earlier, an FC increase of 1.33 of liver IGFBPI messenger was associated with a significant increase in plasma IGFBP1 protein levels in "diabetic" chickens. Furthermore, the decrease in muscle EGRl messenger (FC 0.83) was confirmed by qRTP-CR analysis. Several genes may code for more than one protein; all protein IDs were maintained even though some forms are tissue specific in mammals and most likely in the chicken. In
Fig. 1. Gene interaction network in liver $(A)$ showing genes involved in lipid metabolism and in leg muscle $(B)$ showing genes involved in cellular growth and gene expression after insulin immuno-neutralization in chickens. Upregulated genes are indicated in red and downregulated genes are indicated in green; the number of genes in each category are shown in the legend. Solid lines indicate a direct relationship between genes and dashed lines represent an indirect association determined by Ingenuity Pathway Analysis (IPA).

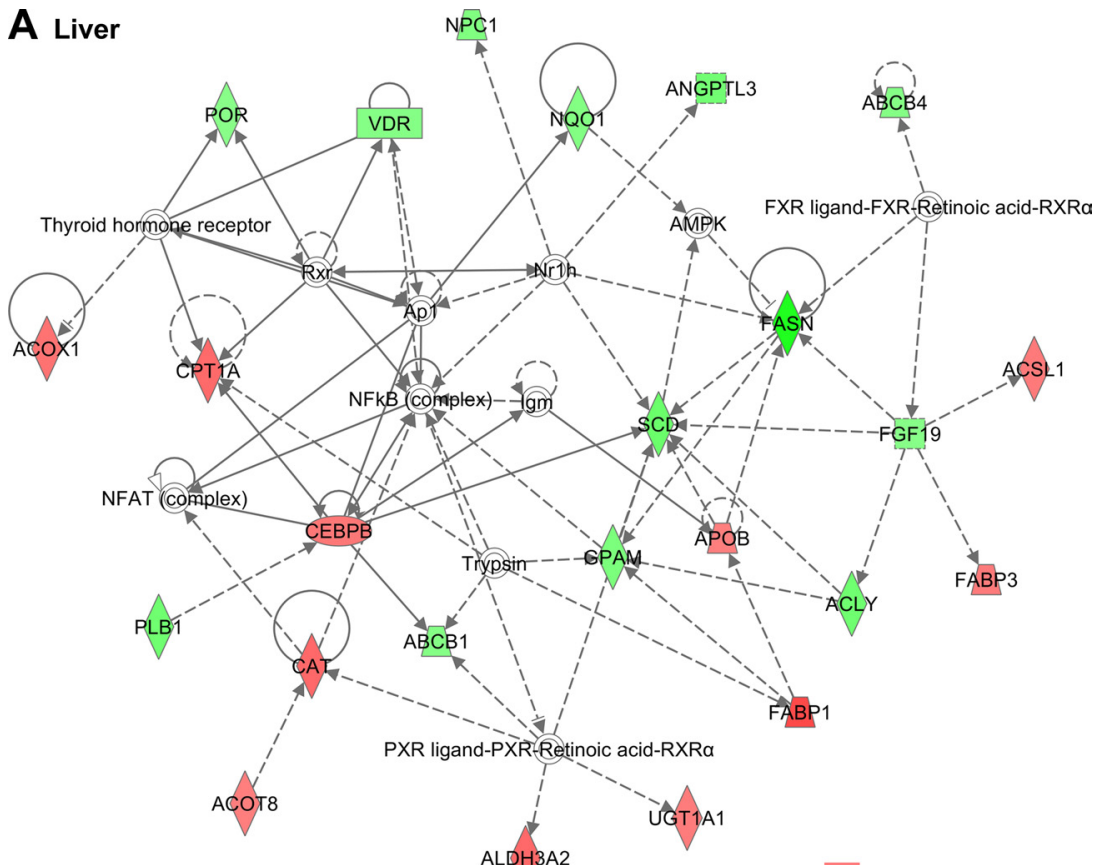

ALDH3A2

11 Up-regulated

13 Down-regulated

$B$
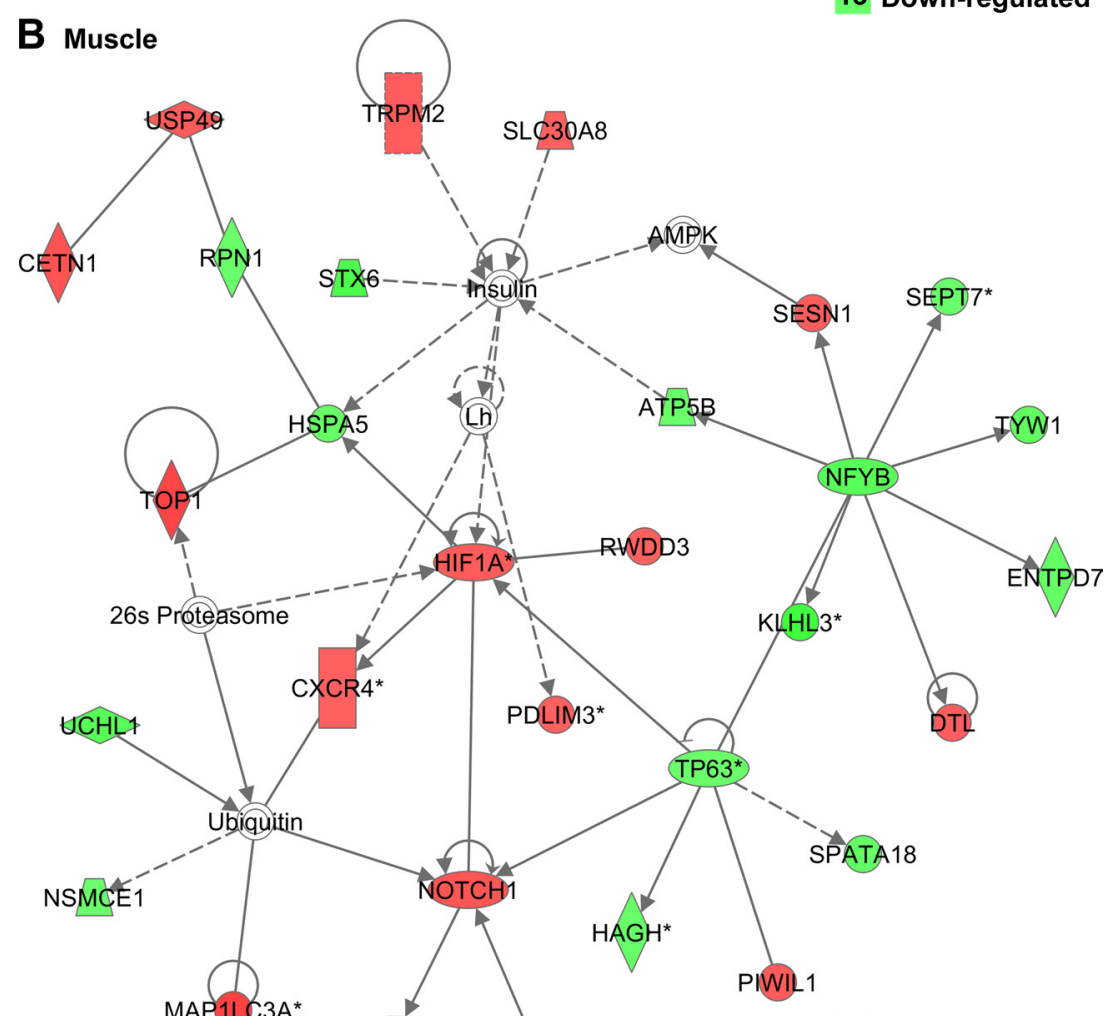

15 Up-regulated 15 Down-regulated 


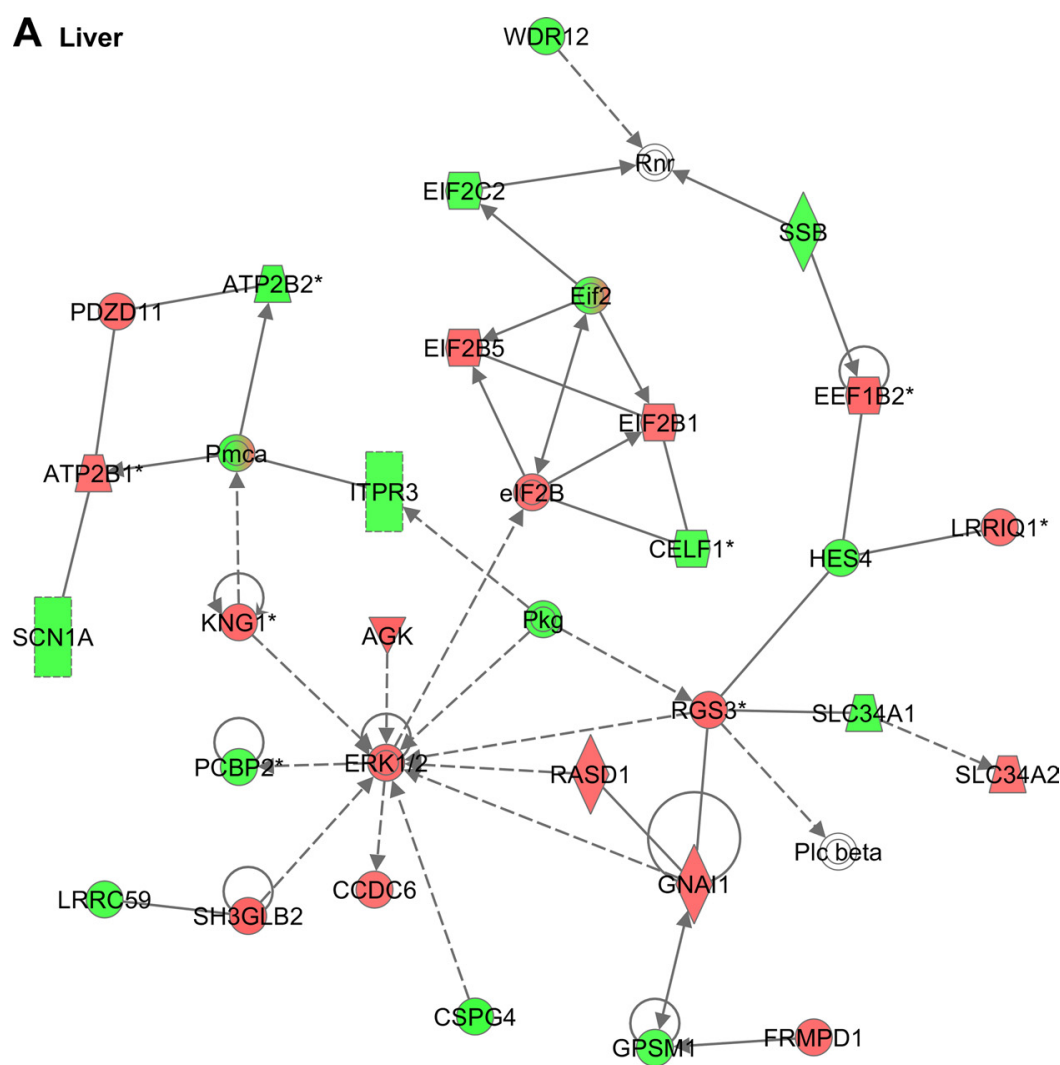

16 Up-regulated 16 Down-regulated

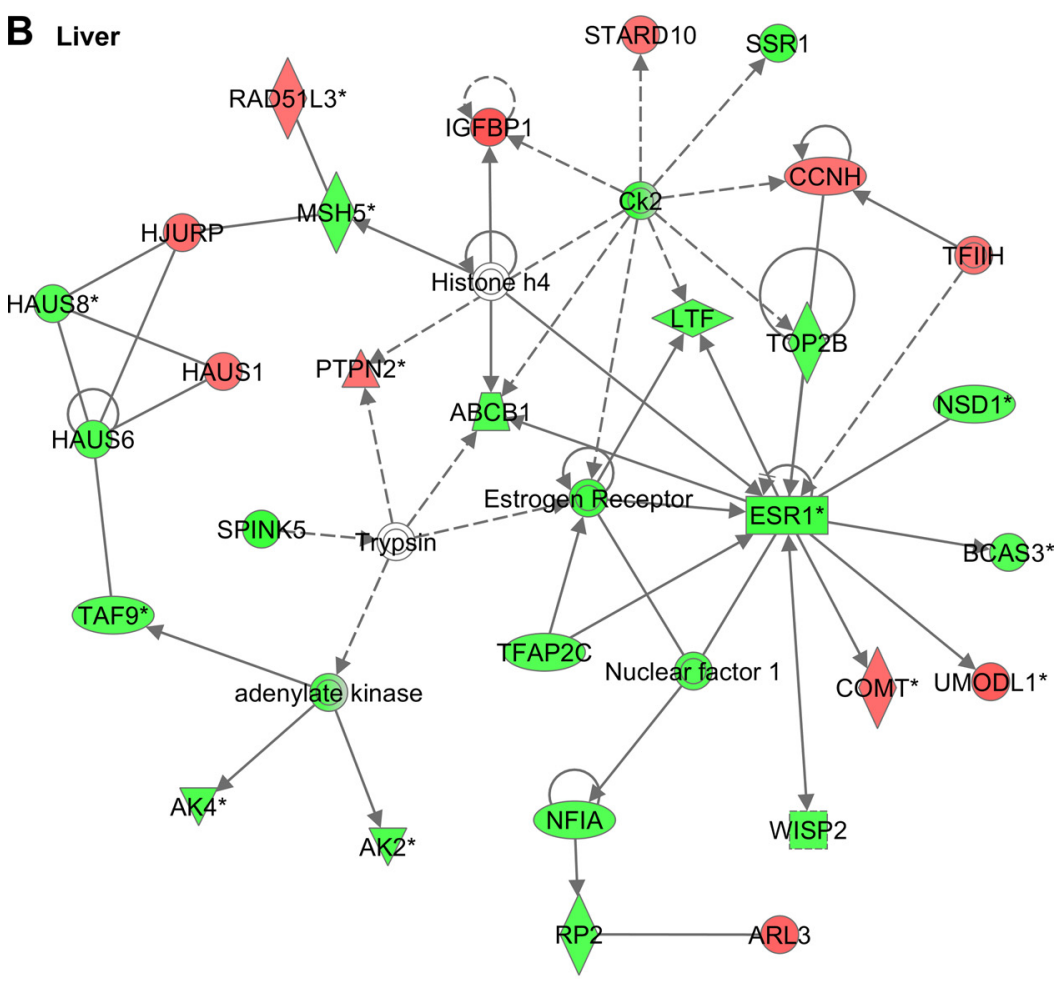

11 Up-regulated 22 Down-regulated
Fig. 2. Gene interaction network in liver after insulin immunoneutralization in chicken showing genes involved in cell signaling $(A)$ and the cell cycle $(B)$. Upregulated genes are indicated in red, and downregulated genes are indicated in green; the number of genes in each category are shown in the legend. Solid lines indicate a direct relationship between genes and dashed lines represent an indirect association determined by IPA. 
Fig. 3. Gene interaction network in leg muscle showing genes involved in the cell cycle $(A)$ and cell apoptosis $(B)$ after insulin immuno-neutralization in chickens revealed by IPA. Upregulated genes are indicated in red and downregulated genes are indicated in green; the number of genes in each category are shown in the legend. Solid lines indicate a direct relationship between genes and dashed lines represent an indirect association determined by IPA.

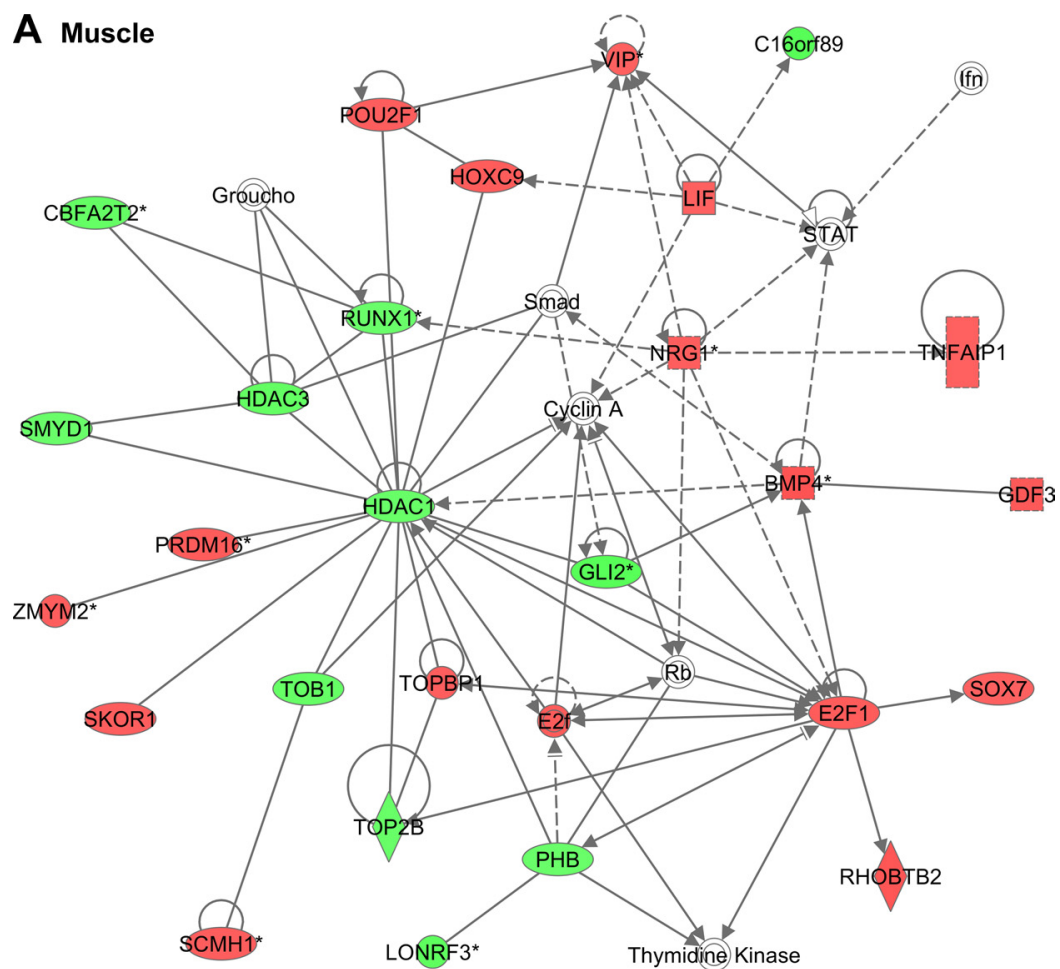

16 Up-regulated

7 Down-regulated

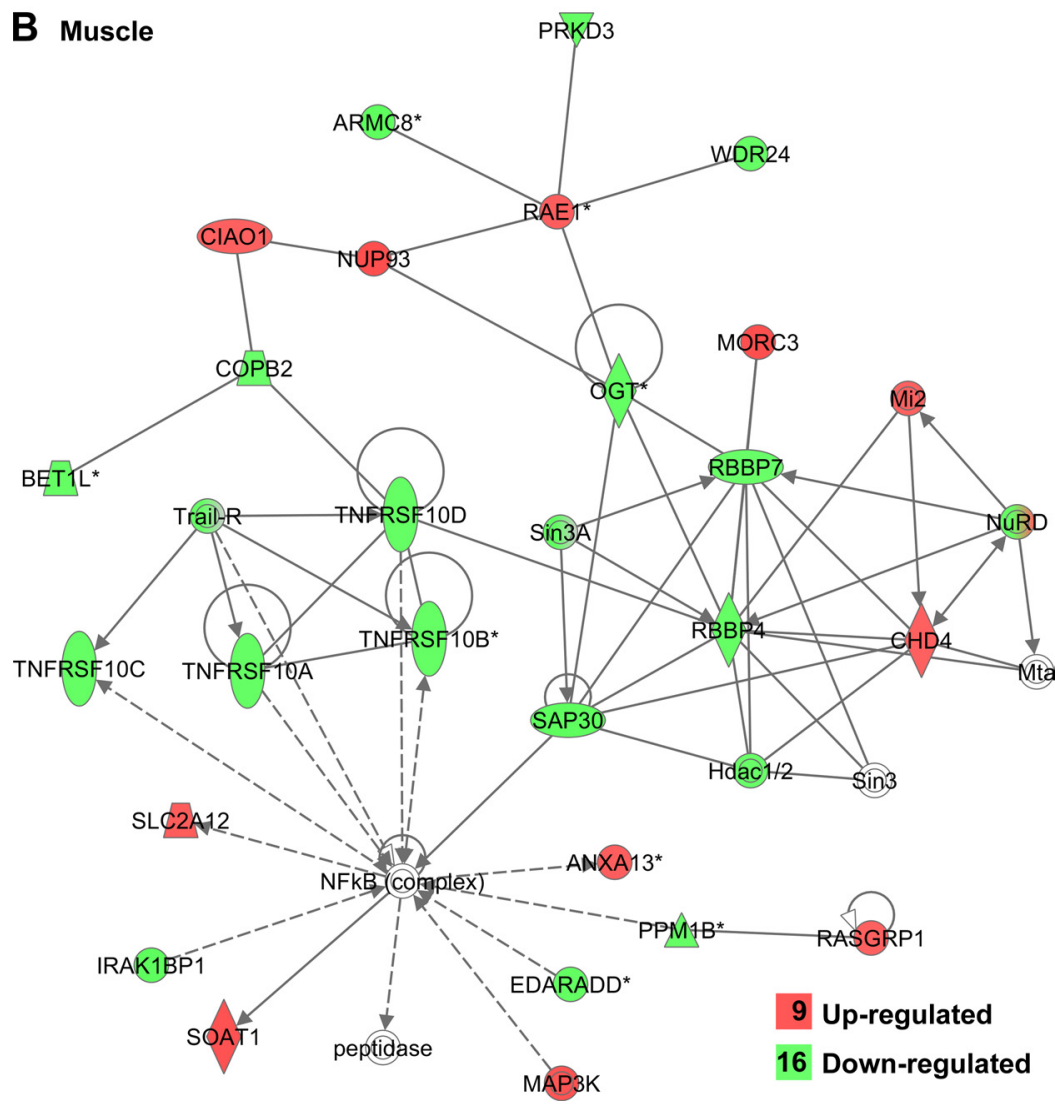




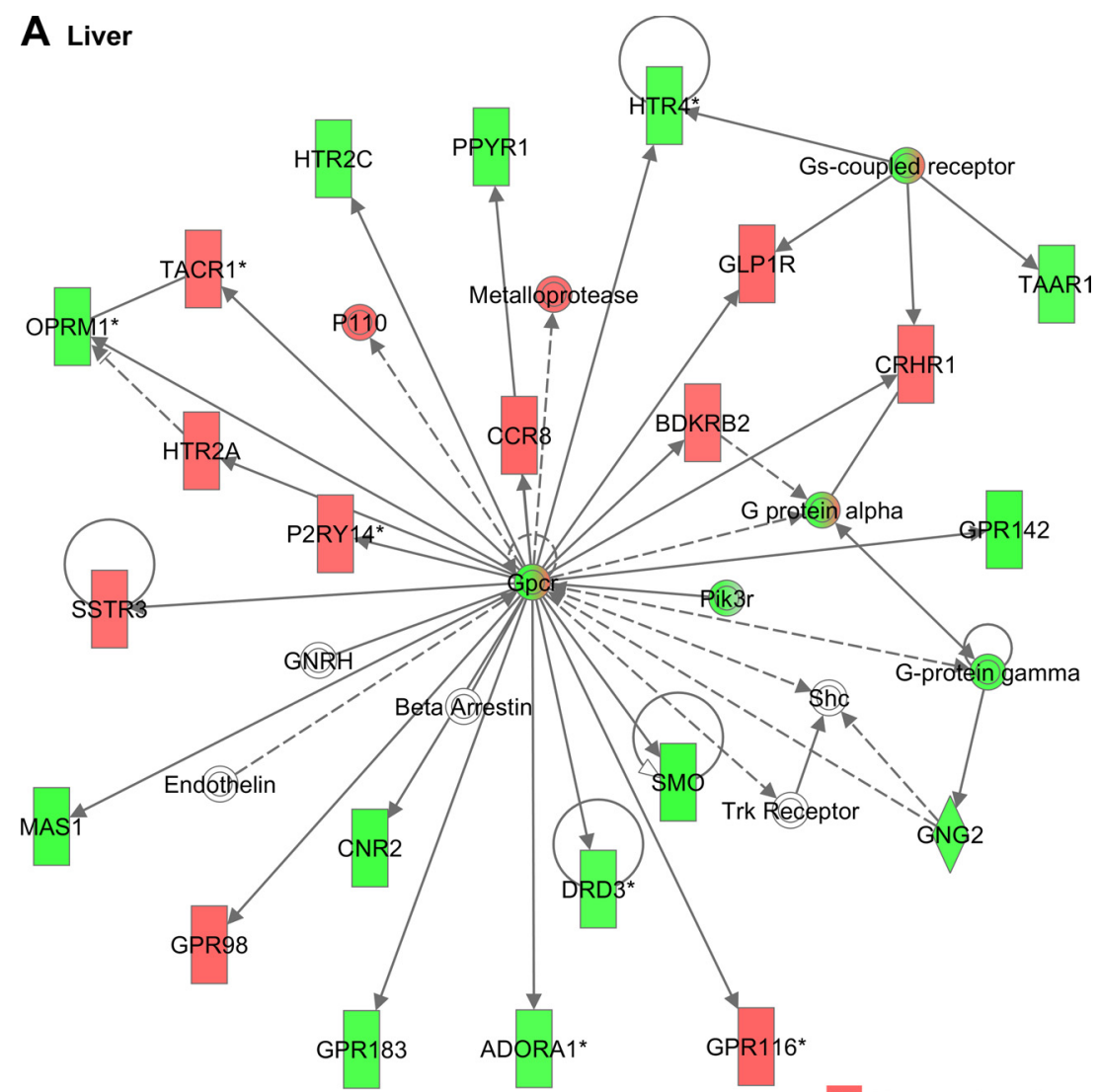

\section{B Muscle}

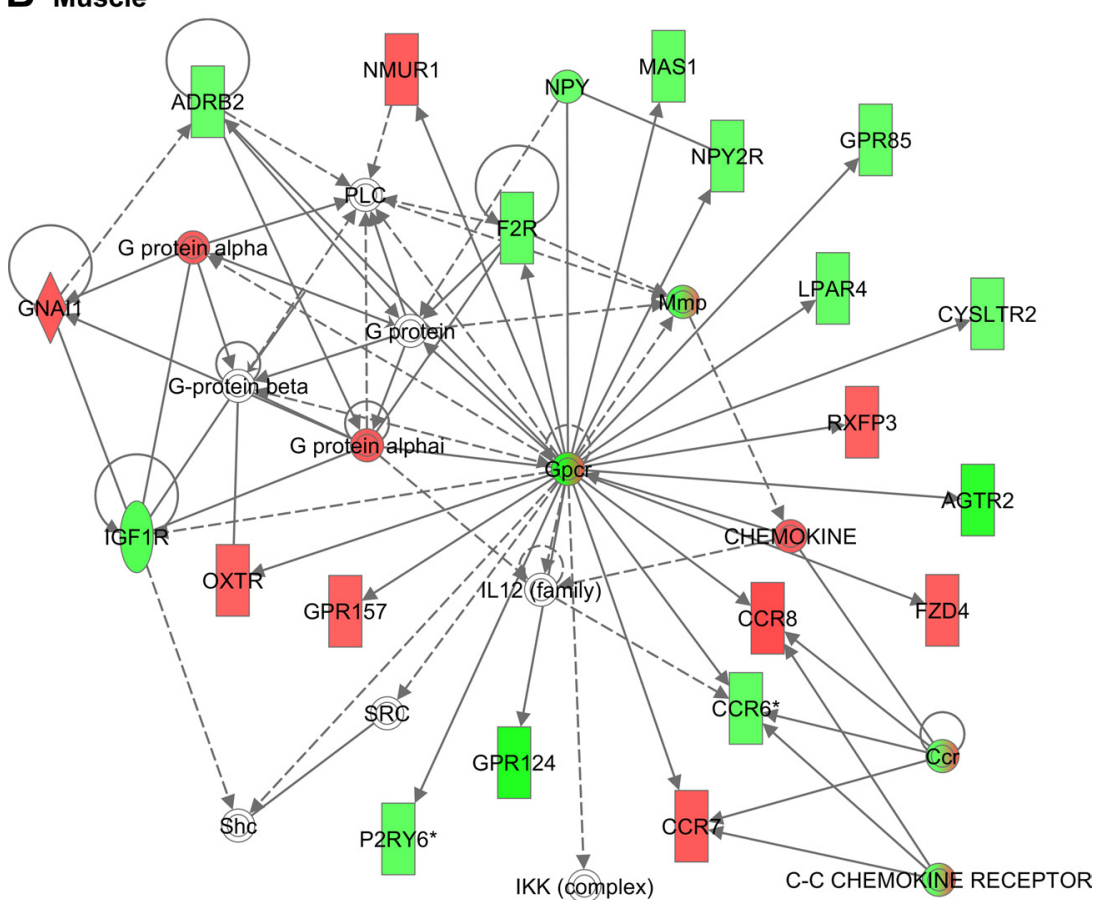

Fig. 4. G-coupled protein receptor/ligand gene interaction networks controlling cell signaling in liver $(A)$ and leg muscle $(B)$ after insulin immuno-neutralization in chickens. Upregulated genes are indicated in red, and downregulated genes are indicated in green; the number of genes in each category are shown in the legend. Solid lines indicate a direct relationship between genes and dashed lines represent an indirect association determined by IPA. 
addition, both liver and skeletal muscles are heterogeneous organs, which allows for the possibility that some mRNAs altered by insulin privation may come from cells different than typical hepatocytes, myotubes, or myocytes. Future studies will have to address these issues and to identify the presence of potentially false positive results. Biorag classifies genes into two main categories: either metabolic pathways or cellular and regulatory pathways with subdivisions. The lists of the genes involved in the major pathways are presented in Supplemental Tables S5 and S6 for liver and Supplemental Tables S7 and S8 for muscle.

IPA software mapped a total of 1,846 pathway-eligible genes from both liver and muscle to the Ingenuity Knowledge Base (http://www.ingenuity.com/). And of these, 991 genes were unique to liver, $741 \mathrm{DE}$ genes were unique to muscle, and $114 \mathrm{DE}$ genes were common to both tissues. IPA emphasized the fact that major biological processes were altered by insulin deprivation in both liver and muscle (Table 2). Table 2 also shows the number of DE genes involved in the different biological processes. In liver, large numbers of genes were associated with metabolic disease (glucose metabolism disorder), endocrine disorders (diabetes mellitus), genetic disorder (obesity), metabolism of lipid (Fig. 1A), carbohydrate and protein, cell signaling (Fig. 2A), and cell cycle (Fig. 2B). In muscle, the largest number of genes was related to skeletal and muscular disorders, metabolic disease (glucose metabolism disorder), endocrine system disorders (diabetes mellitus), genetic disorder (amyotrophic lateral sclerosis), metabolism of lipid, and cell adhesion (Figs. $1 B$ and $3, A$ and $B$ ). IPA identified numerous DE G protein-coupled receptors and growth factor interactions in liver $(n=28)$ and leg muscle $(n=21$; Fig. $4, A$ and $B$, respectively).

An extensive review of DE genes classified in the various pathways revealed that at least 42 mRNAs have already been related to diabetes or obesity or involved in energy expenditure or sensing of metabolism in mice or humans (Table 3). It is worthy to note that three mRNAs from the oxidative pathway were decreased in muscle by the insulin deprivation: ATP synthase subunit beta (ATP5B), cytochrome c oxidase copper chaperone (COX17), and NADH dehydrogenase [ubiquinone] 1 alpha subcomplex subunit 12 (NDUFA12). These genes belong to the "oxphos" gene complex $(29,32)$, which is less expressed in muscles from diabetic patients and has been identified following a gene set enrichment analysis of microarray data. Usual analyses of the same data concluded that no mRNAs were modified in muscles of diabetic humans. Changes appear more pronounced in the present chicken model, which could be accounted for by some physiological characteristics of birds, i.e., their high body temperature, $42^{\circ} \mathrm{C}$ (45), and high metabolic rate (20). In humans and mouse, the expression of "oxphos" genes is most likely coordinated by the transcription factors PGC-1A [peroxisome proliferator-activated receptor gamma, coactivaor 1alpha (PPARGC-1A)] and nuclear respiratory factor 1 [NRF1 $(29,32,40)]$. Neither of these factors appeared in the DE gene lists issued from the present experiment and our earlier qRT-PCR analysis did not reveal any alteration for $P G C-1 A$ messenger at $5 \mathrm{~h}$ of insulin privation (11). Recent studies in humans have shown that alteration in oxphos gene transcription in diabetic humans is not a primary defect but results from dysregulation in metabolism (17).

\section{Conclusions}

Insulin privation rapidly and profoundly modifies global gene transcription in liver and muscle of fed chickens, despite several peculiarities observed in chicken for insulin sensitivity in vivo and insulin signaling in muscle $(11,12)$. The high number of genes altered by insulin deprivation may in part depend on two physiological features of chicken metabolism:

Table 3. Differentially expressed genes known to be associated with energy expenditure, sensing of metabolism, insulin resistance, obesity, or diabetes in mice or humans

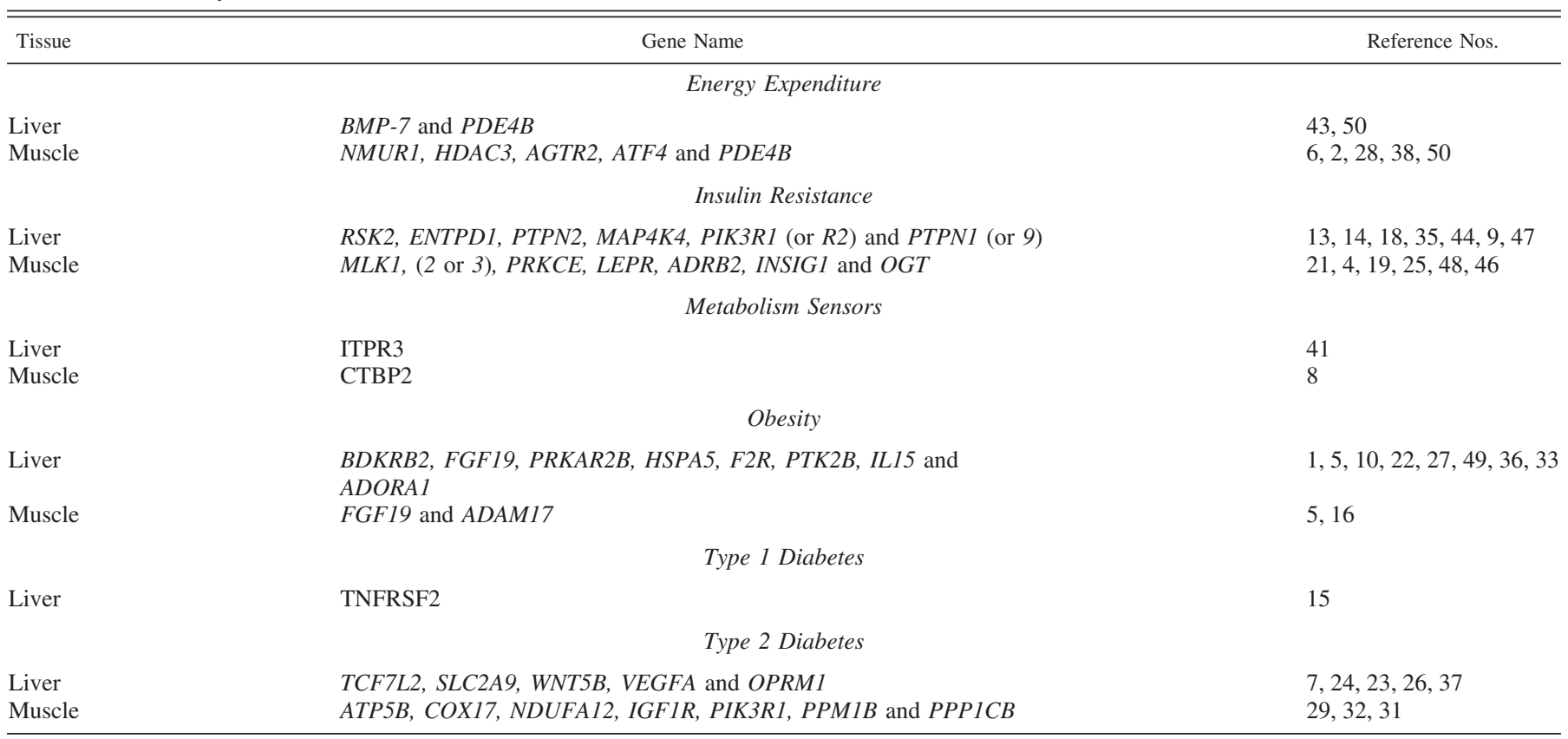


high body temperature $\left[42^{\circ} \mathrm{C},(45)\right]$ and high metabolic rate (20). In both liver and muscle, changes concern components of multiple metabolic pathways, structural proteins, transporters, proteins of intracellular trafficking, major signaling pathways and elements of the transcription control, transcription machinery, and several other biological process. This further demonstrates pleiotropic effects of insulin in the chicken, which are most likely mediated through multiple gene networks. At least $42 \mathrm{DE}$ genes identified by this study in chickens have already been associated with energy expenditure, obesity, diabetes, and/or insulin resistance or identified as metabolic sensors in humans or mice. Therefore, major metabolic, cellular, and regulatory pathways controlled by insulin have been conserved despite some unique features of metabolic control in the chicken. In contrast, a link between the level of gene expression and insulin does not exist for another large number of mRNAs. Future progress in those fields might be helpful for the comprehension of some aspects of diabetes in humans on a comparative point of view. The gene knockout cannot be easily achieved in the chicken; however, several nutritional or genetic models that have been used for studies of insulin signaling could be appropriate and fruitful. Other challenging questions to answer concern the characterization of "unknown" or orphan mRNAs and the identification of the steps or networks, which so quickly permit such a large disturbance of the transcriptome after the turning off of the insulin signal. In the latter issue, one can hypothesize that insulin receptor and components of insulin receptor signaling cascade themselves play a major role within the nucleus. It has recently been shown that this complex is recruited to the promoter region of two insulin-inducible gene ( $E G R 1$ in HTC-IR cells and $G C K$ in mice liver); furthermore this complex is temporarily activated during the expression of these genes (30).

\section{ACKNOWLEDGMENTS}

We gratefully thank Augustin Scalbert for microarray analysis performed in his group, Pascal Froment for helpful discussions, Christine Leroux and Marie Coisnon for advice and help during microarray hybridizations, Karine Hugot and her team at CRB-Gadie for the printing of the microarray slides, Nathaele Wacrenier-Cere for help in formatting of the bibliography, and K. Gérard for care of the chickens.

\section{GRANTS}

This study was made possible through funding from INRA-SRA-Nouzilly and, in part, INRA-Human Nutrition Group at Theix and USDA-IFAFS Grant 00-52100-9614 to L. A. Cogburn, project leader, T. E. Porter and J. Simon (coprincipal investigators). Microarray slides were provided by the Research Group of Yves Nys (SRA-INRA, Nouzilly, France).

\section{DISCLOSURES}

No conflicts of interest, financial or otherwise, are declared by the author(s).

\section{AUTHOR CONTRIBUTIONS}

Author contributions: J.S. and J.D. conception and design of research; J.S., D.M., E.G., A.C., S.M.-C., N.R., S.T., M.D., S.C., E.C.-A., C.G., T.E.P., and M.J.D. performed experiments; J.S., D.M., C.C., C.H.-A., J.D., and L.A.C. analyzed data; J.S., T.E.P., M.J.D., and L.A.C. interpreted results of experiments; J.S. and L.A.C. prepared figures; J.S. drafted manuscript; J.S. and L.A.C. edited and revised manuscript; J.S., D.M., E.G., C.C., A.C., S.M.-C., N.R., S.T., M.D., S.C., E.C.-A., C.H.-A., C.G., T.E.P., M.J.D., J.D., and L.A.C. approved final version of manuscript.

\section{REFERENCES}

1. Abe KC, Mori MA, Pesquero JB. Leptin deficiency leads to the regulation of kinin receptors expression in mice. Regul Pept 138: 56-58, 2007.
2. Alenghat T, Meyers K, Mullican SE, Leitner K, Adeniji-Adele A, Avila J, Bucan M, Ahima RS, Kaestner KH, Lazar MA. Nuclear receptor corepressor and histone deacetylase 3 govern circadian metabolic physiology. Nature 456: 997-1000, 2008.

3. Auclair S, Milenkovic D, Besson C, Chauvet S, Gueux E, Morand C, Mazur A, Scalbert A. Catechin reduces atherosclerotic lesion development in apo E-deficient mice: a transcriptomic study. Atherosclerosis 204: e21-e27, 2009.

4. Barma P, Bhattacharya S, Bhattacharya A, Kundu R, Dasgupta S, Biswas A, Roy SS. Lipid induced overexpression of NF-kappaB in skeletal muscle cells is linked to insulin resistance. Biochim Biophys Acta 1792: 190-200, 2009.

5. Bhatnagar S, Damron HA, Hillgartner FB. Fibroblast growth factor-19, a novel factor that inhibits hepatic fatty acid synthesis. J Biol Chem 284: 10023-10033, 2009.

6. Budhiraja S, Chugh A. Neuromedin U: physiology, pharmacology and therapeutic potential. Fundam Clin Pharmacol 23: 149-157, 2009.

7. Cauchi S, Froguel P. TCF7L2 genetic defect and type 2 diabetes. Curr Diab Rep 8: 149-155, 2008.

8. Chinnadurai G. Transcriptional regulation by C-terminal binding proteins. Int J Biochem Cell Biol 39: 1593-1607, 2007.

9. Cho CY, Koo SH, Wang Y, Callaway S, Hedrick S, Mak PA, Orth AP, Peters EC, Saez E, Montminy M, Schultz PG, Chanda SK. Identification of the tyrosine phosphatase PTP-MEG2 as an antagonist of hepatic insulin signaling. Cell Metab 3: 367-378, 2006.

10. Cummings DE, Brandon EP, Planas JV, Motamed K, Idzerda RL, McKnight GS. Genetically lean mice result from targeted disruption of the RII beta subunit of protein kinase A. Nature 382: 622-626, 1996.

11. Dupont J, Tesseraud S, Derouet M, Collin A, Rideau N, Crochet S, Godet E, Cailleau-Audouin E, Metayer-Coustard S, Duclos MJ, Gespach C, Porter TE, Cogburn LA, Simon J. Insulin immunoneutralization in chicken: effects on insulin signaling and gene expression in liver and muscle. J Endocrinol 197: 531-542, 2008.

12. Dupont J, Tesseraud S, Simon J. Insulin signaling in chicken liver and muscle. Gen Comp Endocrinol 163: 52-57, 2009.

13. El-Haschimi K, Dufresne SD, Hirshman MF, Flier JS, Goodyear LJ, Bjorbaek C. Insulin resistance and lipodystrophy in mice lacking ribosomal S6 kinase 2. Diabetes 52: 1340-1346, 2003.

14. Enjyoji K, Kotani K, Thukral C, Blumel B, Sun X, Wu Y, Imai M, Friedman D, Csizmadia E, Bleibel W, Kahn BB, Robson SC. Deletion of cd39/entpd1 results in hepatic insulin resistance. Diabetes 57: 23112320, 2008.

15. Fas SC, Fritzsching B, Suri-Payer E, Krammer PH. Death receptor signaling and its function in the immune system. Curr Dir Autoimmun 9: $1-17,2006$.

16. Fiorentino L, Vivanti A, Cavalera M, Marzano V, Ronci M, Fabrizi M, Menini S, Pugliese G, Menghini R, Khokha R, Lauro R, Urbani A, Federici M. Increased tumor necrosis factor alpha-converting enzyme activity induces insulin resistance and hepatosteatosis in mice. Hepatology 51: 103-110, 2010.

17. Frederiksen CM, Hojlund K, Hansen L, Oakeley EJ, Hemmings B, Abdallah BM, Brusgaard K, Beck-Nielsen H, Gaster M. Transcriptional profiling of myotubes from patients with type 2 diabetes: no evidence for a primary defect in oxidative phosphorylation genes. Diabetologia 51: 2068-2077, 2008

18. Galic S, Hauser C, Kahn BB, Haj FG, Neel BG, Tonks NK, Tiganis T. Coordinated regulation of insulin signaling by the protein tyrosine phosphatases PTP1B and TCPTP. Mol Cell Biol 25: 819-829, 2005.

19. Hennige AM, Stefan N, Kapp K, Lehmann R, Weigert C, Beck A, Moeschel K, Mushack J, Schleicher E, Haring HU. Leptin downregulates insulin action through phosphorylation of serine-318 in insulin receptor substrate 1. FASEB J 20: 1206-1208, 2006.

20. Holmes DJ, Fluckiger R, Austad SN. Comparative biology of aging in birds: an update. Exp Gerontol 36: 869-883, 2001.

21. Jaeschke A, Davis RJ. Metabolic stress signaling mediated by mixedlineage kinases. Mol Cell 27: 498-508, 2007.

22. Kammoun HL, Chabanon H, Hainault I, Luquet S, Magnan C, Koike T, Ferre P, Foufelle F. GRP78 expression inhibits insulin and ER stress-induced SREBP-1c activation and reduces hepatic steatosis in mice. J Clin Invest 119: 1201-1215, 2009.

23. Kanazawa A, Tsukada S, Sekine A, Tsunoda T, Takahashi A, Kashiwagi A, Tanaka Y, Babazono T, Matsuda M, Kaku K, Iwamoto Y, Kawamori R, Kikkawa R, Nakamura Y, Maeda S. Association of the gene encoding wingless-type mammary tumor virus integration-site fam- 
ily member 5B (WNT5B) with type 2 diabetes. Am J Hum Genet 75: 832-843, 2004.

24. Keembiyehetty C, Augustin R, Carayannopoulos MO, Steer S, Manolescu A, Cheeseman CI, Moley KH. Mouse glucose transporter 9 splice variants are expressed in adult liver and kidney and are up-regulated in diabetes. Mol Endocrinol 20: 686-697, 2006.

25. Lessard SJ, Rivas DA, Chen ZP, van Denderen BJ, Watt MJ, Koch LG, Britton SL, Kemp BE, Hawley JA. Impaired skeletal muscle beta-adrenergic activation and lipolysis are associated with whole-body insulin resistance in rats bred for low intrinsic exercise capacity. Endocrinology 150: 4883-4891, 2009.

26. Lindenmeyer MT, Kretzler M, Boucherot A, Berra S, Yasuda Y, Henger A, Eichinger F, Gaiser S, Schmid H, Rastaldi MP, Schrier RW, Schlondorff D, Cohen CD. Interstitial vascular rarefaction and reduced VEGF-A expression in human diabetic nephropathy. J Am Soc Nephrol 18: 1765-1776, 2007.

27. Luyendyk JP, Sullivan BP, Guo GL, Wang R. Tissue factor-deficiency and protease activated receptor-1-deficiency reduce inflammation elicited by diet-induced steatohepatitis in mice. Am J Pathol 176: 177-186, 2010.

28. Miyashita K, Itoh H, Tsujimoto H, Tamura N, Fukunaga Y, Sone M, Yamahara K, Taura D, Inuzuka M, Sonoyama T, Nakao K. Natriuretic peptides/cGMP/cGMP-dependent protein kinase cascades promote muscle mitochondrial biogenesis and prevent obesity. Diabetes 58: 2880-2892, 2009.

29. Mootha VK, Lindgren CM, Eriksson KF, Subramanian A, Sihag S, Lehar J, Puigserver P, Carlsson E, Ridderstrale M, Laurila E, Houstis N, Daly MJ, Patterson N, Mesirov JP, Golub TR, Tamayo P, Spiegelman B, Lander ES, Hirschhorn JN, Altshuler D, Groop LC. PGC1alpha-responsive genes involved in oxidative phosphorylation are coordinately downregulated in human diabetes. Nat Genet 34: 267-273, 2003.

30. Nelson JD, LeBoeuf RC, Bomsztyk K. Direct recruitment of insulin receptor and ERK signaling cascade to insulin-inducible gene loci. Diabetes 60: 127-137, 2011.

31. Palsgaard J, Brons C, Friedrichsen M, Dominguez H, Jensen M, Storgaard H, Spohr C, Torp-Pedersen C, Borup R, De Meyts P, Vaag A. Gene expression in skeletal muscle biopsies from people with type 2 diabetes and relatives: differential regulation of insulin signaling pathways. PLoS One 4: e6575, 2009.

32. Patti ME, Butte AJ, Crunkhorn S, Cusi K, Berria R, Kashyap S, Miyazaki Y, Kohane I, Costello M, Saccone R, Landaker EJ, Goldfine AB, Mun E, DeFronzo R, Finlayson J, Kahn CR, Mandarino LJ. Coordinated reduction of genes of oxidative metabolism in humans with insulin resistance and diabetes: potential role of PGC1 and NRF1. Proc Natl Acad Sci USA 100: 8466-8471, 2003.

33. Peng Z, Borea PA, Varani K, Wilder T, Yee H, Chiriboga L, Blackburn MR, Azzena G, Resta G, Cronstein BN. Adenosine signaling contributes to ethanol-induced fatty liver in mice. J Clin Invest 119: 582-594, 2009.

34. Proszkowiec-Weglarz M, Richards MP, Ramachandran R, McMurtry JP. Characterization of the AMP-activated protein kinase pathway in chickens. Comp Biochem Physiol B Biochem Mol Biol 143: 92-106, 2006.

35. Puri V, Virbasius JV, Guilherme A, Czech MP. RNAi screens reveal novel metabolic regulators: RIP140, MAP4k4 and the lipid droplet asso- ciated fat specific protein (FSP) 27. Acta Physiol (Oxf) 192: 103-115, 2008.

36. Quinn LS, Anderson BG, Strait-Bodey L, Stroud AM, Argiles JM. Oversecretion of interleukin-15 from skeletal muscle reduces adiposity. Am J Physiol Endocrinol Metab 296: E191-E202, 2009.

37. Ruchat SM, Girard M, Weisnagel SJ, Bouchard C, Vohl MC, Perusse L. Association between mu-opioid receptor-1 $102 \mathrm{~T}>\mathrm{C}$ polymorphism and intermediate type 2 diabetes phenotypes: results from the Quebec Family Study (QFS). Clin Exp Pharmacol Physiol 35: 1018-1022, 2008.

38. Seo J, Fortuno ES 3rd, Suh JM, Stenesen D, Tang W, Parks EJ, Adams CM, Townes T, Graff JM. Atf4 regulates obesity, glucose homeostasis, and energy expenditure. Diabetes 58: 2565-2573, 2009.

39. Simon J, Rideau N, Taouis M, Dupont J. Plasma insulin levels are rather similar in chicken and rat. Gen Comp Endocrinol 171: 267-268, 2011.

40. Skov V, Glintborg D, Knudsen S, Jensen T, Kruse TA, Tan Q, Brusgaard K, Beck-Nielsen H, Hojlund K. Reduced expression of nuclear-encoded genes involved in mitochondrial oxidative metabolism in skeletal muscle of insulin-resistant women with polycystic ovary syndrome. Diabetes 56: 2349-2355, 2007.

41. Srivastava M, Eidelman O, Leighton X, Glasman M, Goping G, Pollard HB. Anx7 is required for nutritional control of gene expression in mouse pancreatic islets of Langerhans. Mol Med 8: 781-797, 2002.

42. Sun G. Application of DNA microarrays in the study of human obesity and type 2 diabetes. OMICS 11: 25-40, 2007.

43. Tseng YH, Kokkotou E, Schulz TJ, Huang TL, Winnay JN, Taniguchi CM, Tran TT, Suzuki R, Espinoza DO, Yamamoto Y, Ahrens MJ, Dudley AT, Norris AW, Kulkarni RN, Kahn CR. New role of bone morphogenetic protein 7 in brown adipogenesis and energy expenditure. Nature 454: 1000-1004, 2008.

44. Ueki K, Fruman DA, Yballe CM, Fasshauer M, Klein J, Asano T, Cantley LC, Kahn CR. Positive and negative roles of p85 alpha and p85 beta regulatory subunits of phosphoinositide 3-kinase in insulin signaling. J Biol Chem 278: 48453-48466, 2003.

45. Walter I, Hegarty B, Seebacher F. AMP-activated protein kinase controls metabolism and heat production during embryonic development in birds. J Exp Biol 213: 3167-3176, 2010.

46. Wu X, Wang J, Cui X, Maianu L, Rhees B, Rosinski J, So WV, Willi SM, Osier MV, Hill HS, Page GP, Allison DB, Martin M, Garvey WT. The effect of insulin on expression of genes and biochemical pathways in human skeletal muscle. Endocrine 31: 5-17, 2007.

47. Xue B, Kim YB, Lee A, Toschi E, Bonner-Weir S, Kahn CR, Neel BG, Kahn BB. Protein-tyrosine phosphatase 1B deficiency reduces insulin resistance and the diabetic phenotype in mice with polygenic insulin resistance. J Biol Chem 282: 23829-23840, 2007.

48. Yang X, Ongusaha PP, Miles PD, Havstad JC, Zhang F, So WV, Kudlow JE, Michell RH, Olefsky JM, Field SJ, Evans RM. Phosphoinositide signalling links O-GlcNAc transferase to insulin resistance. Nature 451: 964-969, 2008

49. Yu Y, Ross SA, Halseth AE, Hollenbach PW, Hill RJ, Gulve EA, Bond BR. Role of PYK2 in the development of obesity and insulin resistance. Biochem Biophys Res Commun 334: 1085-1091, 2005.

50. Zhang R, Maratos-Flier E, Flier JS. Reduced adiposity and high-fat diet-induced adipose inflammation in mice deficient for phosphodiesterase 4B. Endocrinology 150: 3076-3082, 2009. 